\title{
CONTRA OS DIREITOS HUMANOS ${ }^{1}$
}

\author{
Slavoj Žižek ${ }^{2}$
}

\begin{abstract}
Resumo
Álibi para intervenções militares, sacralização para a tirania do mercado, base ideológica para o fundamentalismo do politicamente correto: pode a "ficção simbólica" dos direitos universais ser recuperada com vistas a uma politização progressiva das relações sócio-econômicas vigentes?
\end{abstract}

Palavras-chave: Direitos humanos. Universalidade. Capitalismo liberal.

\begin{abstract}
Against human Rights

Alibi for militarist interventions, sacralization for the tyranny of the market, ideological foundation for the fundamentalism of the politically correct: can the 'symbolic fiction' of universal rights be recuperated for the progressive politicization of actual socio-economic relations?
\end{abstract}

Keywords: Human Rights. Universality. Liberal-capitalism.

\footnotetext{
${ }^{1}$ Versão original publicada na New Left Review, n. 34, julho-agosto de 2005, sob o título "Against Human Rights". A Comissão Editorial da revista Mediações agradece aos editores por autorizarem esta publicação. Traduzido do inglês por Sávio Cavalcante. Revisão de Martha Ramírez-Gálvez e Silvana Mariano.

${ }^{2}$ Filósofo, pesquisador da Universidade de Ljubljana (Eslovênia). Autor, dentre outros livros, de $A$ visão em paralaxe (2008) e Lacrimae rerum: ensaios sobre cinema moderno (2009), pela Boitempo, São Paulo.
} 
s invocações contemporâneas aos diretos humanos, em nossas sociedades
liberal-capitalistas, geralmente repousam sobre três suposições. A primeira,
que tais invocações funcionam em oposição a fundamentalismos que naturalizariam ou essencializam traços contingentes historicamente condicionados. A segunda, que os dois direitos mais fundamentais são a liberdade de escolha e o direito de dedicar a própria vida à busca do prazer (ao invés de sacrificá-la por alguma causa ideológica maior). A terceira, que a invocação aos direitos humanos pode formar as bases para uma defesa contra o "excesso de poder".

Comecemos com o fundamentalismo. Aqui, o mal (para parafrasear Hegel) reside frequentemente no olhar que o percebe. Tomemos os Bálcãs durante a década de 1990, lugar de generalizadas violações aos direitos humanos. Em que ponto os Bálcãs - uma região geográfica do sudeste europeu - se "balcanizaram", com tudo o que esse termo designa para o imaginário ideológico europeu de hoje? A resposta é: no período de meados do século XIX, momento em que os Bálcãs foram completamente expostos aos efeitos da modernização europeia. A diferença [gap] entre as primeiras percepções da Europa ocidental e a imagem "moderna" é impressionante. Já no século XVI, o naturalista francês Peirre Belon podia assinalar que "os turcos não forçam ninguém a viver como turco". Pouco surpreende, então, que tantos judeus encontraram asilo e liberdade religiosa na Turquia e em outros países muçulmanos, depois que Fernando e Isabel os expulsaram da Espanha em 1492 - com o resultado de que, num supremo toque de ironia, viajantes ocidentais foram incomodados pela presença pública de judeus nas grandes cidades turcas. Eis aqui, dentre uma longa série de exemplos, um relato de N. Bisani, um italiano que visitou Istambul em 1788:

Um estrangeiro, que tenha contemplado a intolerância de Londres e Paris, deve ter ficado muito surpreso ao ver aqui uma igreja entre uma mesquita e uma sinagoga, e um dervixe ao lado de um frade capuchinho. Eu não sei como este governo pode admitir em seu seio religiões tão opostas à sua própria. Deve ser por uma degenerescência do maometanismo que este feliz contraste pode ser produzido. 0 que é ainda mais surpreendente é encontrar este espírito de tolerância prevalecendo geralmente entre as pessoas; porque aqui você vê turcos, judeus, católicos, armênios, gregos e protestantes conversando juntos sobre assuntos de negócios ou de lazer, com tanta harmonia e boa vontade como se eles fossem do mesmo país e religião (apud JEZERNIK, 2004, p. 233). 
A mesma característica que o Ocidente hoje celebra como um sinal de sua superioridade cultural - 0 espírito e a prática da tolerância multicultural - é repudiado, então, como um efeito da degenerescência islâmica. 0 estranho destino dos monges trapistas do Etoile Marie é igualmente revelador. Expulsos da França pelo regime napoleônico, eles se instalaram na Alemanha, mas também foram expulsos em 1868. Como nenhum outro Estado cristão os acolheria, eles pediram permissão ao Sultão para comprar terras perto de Banja Luka, na parte sérvia da atual Bósnia, onde eles viveram felizes para sempre - até que se viram pegos nos conflitos dos Bálcãs entre cristãos.

Onde, então, se originaram os traços fundamentalistas - intolerância religiosa, violência étnica, fixação em trauma histórico - que o Ocidente agora associa com "os Bálcãs"? Claramente, no próprio Ocidente. Em um claro exemplo da "determinação reflexiva" de Hegel, o que os europeus ocidentais observam e deploram nos Bálcãs é o que eles mesmos introduziram ali, o que eles combatem é o seu próprio legado histórico descontrolado. Não esqueçamos que os dois grandes crimes étnicos imputados aos turcos no século XX - o genocídio de armênios e a perseguição dos curdos - não foram cometidos por forças políticas muçulmanas tradicionalistas, mas pelos modernizadores militares que buscaram separar a Turquia de seu lastro no mundo antigo e transformá-la em um Estado-nação europeu. 0 velho sarcasmo de Mladen Dolar, baseado em uma leitura detalhada das referências de Freud à região, que dizia que o inconsciente europeu é estruturado como os Bálcãs, é, assim, literalmente correto: sob o disfarce de alteridade do "balcânico", a Europa toma conhecimento do "estrangeiro que há em si mesma", de seu eu reprimido.

Mas, deveríamos examinar os modos pelos quais a essencialização fundamentalista dos traços contingentes é, ela mesma, uma característica da democracia liberal-capitalista. Está na moda queixar-se de que a vida privada está sob ameaça ou mesmo desaparecendo em face da habilidade dos meios de comunicação de expor em público os detalhes pessoais mais íntimos. Correto, com a condição de que coloquemos as coisas ao contrário: o que está efetivamente desaparecendo aqui é a vida pública em si, a esfera pública propriamente dita, na qual se opera como um agente simbólico que não pode ser reduzido a um indivíduo privado, a um feixe de atributos, desejos, traumas e idiossincrasias pessoais. 0 lugarcomum "sociedade de risco" - de acordo com o qual o indivíduo contemporâneo experimenta a si mesmo como algo completamente "desnaturalizado", mesmo em relação às suas características mais naturais, desde identidade étnica à preferência 
sexual, como sendo escolhidas, historicamente contingentes, aprendidas - é, então, profundamente enganador. 0 que testemunhamos hoje é o processo oposto: uma re-naturalização sem precedentes. Todas as grandes "questões públicas" são agora traduzidas em atitudes para uma regulação de idiossincrasias "naturais" ou "pessoais".

Isto explica por que, em um plano mais geral, conflitos etno-religiosos pseudo-naturalizados são a forma de luta que mais se ajusta ao capitalismo global. Na era da "pós-política", quando a política propriamente dita é progressivamente substituída por uma administração social de especialistas, as únicas fontes de conflito restantes são as tensões culturais (religiosas) ou naturais (étnicas). E a "avaliação" é precisamente a regulação da promoção social que se encaixa com esta re-naturalização. Talvez tenha chegado o momento de reafirmar, como uma verdade da avaliação, a lógica perversa à qual Marx se refere ironicamente em sua discrição do fetichismo da mercadoria, ao citar o conselho de Dogberry a Seacol, no final do capítulo I de 0 Capital: "Ser um homem bem apessoado é um dom das circunstâncias, mas saber ler e escrever vem da natureza". Ser um especialista em computadores ou um administrador de sucesso é, nos dias de hoje, um dom da natureza, mas ter lábios e olhos belos é uma questão de cultura.

\section{A AUSÊNCIA DA LIBERDADE DE ESCOLHA}

Quanto à liberdade de escolha: escrevi alhures sobre a pseudo-escolha oferecida aos adolescentes das comunidades Amish, que, depois da mais rigorosa educação, são convidados, aos dezessete anos, a mergulhar em todos os excessos da cultura capitalista contemporânea - um turbilhão de carros rápidos, sexo selvagem, drogas, bebidas e assim por diante 3 . Depois de dois anos, lhes é permitido escolher se querem voltar ao modo amish. Como foram criados quase que totalmente ignorantes em relação à sociedade estadunidense, os jovens estão muito despreparados para lidar com tal permissividade, a qual, na maioria dos casos, gera uma reação de ansiedade insuportável. A grande maioria decide por retornar à reclusão de suas comunidades. Este é um perfeito exemplo das dificuldades que invariavelmente acompanham a "liberdade de escolha": ainda que aos jovens amish lhes seja dada formalmente uma livre escolha, as condições nas quais eles têm que fazê-la tornam a escolha não livre.

3 "The constitution is dead. Long live proper politics", Guardian, 4 June 2005. 
0 problema da pseudo-escolha também demonstra os limites das atitudes liberais padrão em relação às mulheres muçulmanas que usam o véu: é aceitável se for sua própria escolha e não algo imposto por seus maridos ou família. Entretanto, no momento em que a mulher usa o véu como resultado de uma escolha pessoal, o significado muda completamente: não é mais um sinal de pertencimento à comunidade muçulmana, mas uma expressão de uma individualidade idiossincrática. Em outras palavras, uma escolha é sempre uma meta-escolha, uma decisão da modalidade da escolha em si: é somente a mulher que escolhe não usar o véu quem, efetivamente, faz uma escolha. Por esta razão, em nossas democracias liberais seculares, as pessoas que mantém uma fidelidade religiosa substancial estão em posições subordinadas: sua fé é "tolerada" por ser sua própria escolha pessoal, mas no momento em que a apresentam publicamente como o que a fé é para elas - uma questão de pertencimento substancial - são acusadas de "fundamentalismo". Obviamente, o "tema da livre escolha", no sentido "tolerante", multicultural, pode apenas emergir como resultado de um processo extremamente violento de desenraizamento do mundo e da vida particular de cada um.

A força essencial da noção ideológica de "livre escolha" na democracia capitalista foi bem ilustrada pelo destino do ultra-modesto programa de reforma da saúde da administração de Clinton. 0 lobby médico (duas vezes mais forte que o infame lobby da Defesa) obteve sucesso em impor ao público a ideia de que a assistência universal de saúde ameaçaria, de alguma maneira, a liberdade de escolher naquele campo. Contra esta conviç̧ão, toda enumeração de "dados puros" provou-se inútil. Aqui estamos no verdadeiro centro nervoso da ideologia liberal: a liberdade de escolha, fundamentada na noção de sujeito "psicológico", dotada de propensões que ele ou ela esforçam-se para concretizar. E isto se mantém especialmente nos dias de hoje, na era da "sociedade do risco", na qual a ideologia dominante se esforça para nos vender as mesmas inseguranças causadas pelo desmantelamento do Welfare State como se fossem oportunidades para novas liberdades. Se a flexibilização do trabalho significa que você tem que mudar de emprego todos os anos, por que não ver isto como uma liberação dos constrangimentos de uma carreira permanente, uma chance de se reinventar e de desenvolver o potencial oculto de sua personalidade? Se existe uma redução de seu seguro de saúde padrão e de seu plano de aposentadoria, o que significa que você tem que optar por uma cobertura extra? Por que não perceber isto como uma oportunidade adicional para escolher entre um melhor estilo de vida agora ou a 
seguridade em longo prazo? Se este apuro lhe causa ansiedade, os ideólogos da "segunda modernidade" irão diagnosticar que você deseja "escapar da liberdade", de que está apegado imaturamente a velhas formas estáveis. Melhor ainda, quando isto está inscrito na ideologia do sujeito enquanto indivíduo "psicológico", prenhe de habilidades individuais, a pessoa tenderá automaticamente a interpretar todas essas mudanças como resultado de sua personalidade, e não como resultado de ter sido sacudida pelas forças do mercado.

\section{A POLÍ́TICA DA JOUISSANCE}

E o que dizer do direito básico à busca do prazer? A política de hoje preocupa-se cada vez mais com as formas de solicitar ou controlar a jouissance ${ }^{4}$. A oposição entre o Ocidente liberal-tolerante e 0 Islã-fundamentalista se condensa mais frequentemente como a oposição entre, por um lado, o direito da mulher à livre sexualidade, incluindo a liberdade de se mostrar ou de se expor e provocar ou incomodar os homens; e, por outro lado, tentativas masculinas desesperadas em suprimir ou controlar esta ameaça. (Os talibãs proibiam as mulheres de usar saltos com pontas metálicas, pois os sons das batidas, vindas debaixo das burcas que a tudo tapam, poderiam causar um apelo erótico irresistível).

Ambos os lados, por certo, mistificam ideológica e moralmente suas posições. Para o Ocidente, o direito das mulheres a se expor de forma provocativa ao desejo masculino é legitimado como seu direito de desfrutar de seus corpos como bem entendem. Para o Islã, o controle sobre a sexualidade feminina é legitimado pela defesa da dignidade da mulher em oposição à sua redução a objetos de exploração masculina. Assim, quando o Estado francês proíbe garotas muçulmanas de usar o véu na escola, pode-se alegar que a elas se permite, então, dispor de seus corpos tal como desejam. Mas, também, pode-se dizer que 0 verdadeiro ponto traumático para os críticos do "fundamentalismo" muçulmano foi o fato de que há mulheres que não participaram do jogo de deixar seus corpos disponíveis para sedução sexual, ou para a circulação e trocas sociais envolvidas nisso. De um jeito ou de outro, todas as demais questões - o casamento entre homossexuais e a possibilidade de adoção, do aborto, do divórcio - se referem a este fato. 0 que os dois pólos compartilham é uma abordagem disciplinar estrita, dirigida de diferentes maneiras: os "fundamentalistas" regulam a auto-exibição feminina para prevenir provocações sexuais; os liberais feministas politicamente

${ }^{4}$ N. T. Em francês, no original, "gozo". 
corretos impõem uma regulação não menos severa do comportamento, com 0 objetivo de conter formas de assédio.

As atitudes liberais para o outro são caracterizadas tanto pelo respeito à alteridade, a abertura a ela, quanto pelo medo obsessivo do assédio. Em suma, o outro é acolhido na medida em que sua presença não é intrusiva, na medida em que não seja, na verdade, o outro. A tolerância, portanto, coincide com o seu oposto. Meu dever de ser tolerante para com os outros significa, na verdade que não devo chegar muito próximo a ele ou ela, não me introduzir em seu espaço - em suma, que devo respeitar sua intolerância em relação ao meu excesso de proximidade. Isto está emergindo cada vez mais como direito humano central da sociedade capitalista avançada: o direito a não ser assediado, isto é, a se manter a uma distância segura dos outros. 0 mesmo vale para a emergente lógica do militarismo humanitário ou pacifista. A guerra é aceitável na medida em que procura trazer a paz, ou a democracia, ou as condições para distribuir a ajuda humanitária. E 0 mesmo não é válido para a democracia e para os próprios direitos humanos? Está tudo bem com os direitos humanos se eles são "repensados" para incluir a tortura e um Estado de emergência permanente. Está tudo bem com a democracia se ela está livre de seus excessos populistas e limitada àqueles suficientemente maduros para praticá-la.

Pegos no ciclo vicioso do imperativo da jouissance, a tentação é optar pelo que aparece como seu oposto "natural", a renúncia violenta da jouissance. Este é, talvez, o motivo subjacente de todos os assim chamados fundamentalismos - 0 empenho em conter (aquilo que eles percebem como) o excessivo "narcisismo hedonista" da cultura laica contemporânea com um chamado a reintroduzir o espírito do sacrifício. Uma perspectiva psicanalítica nos permite ver, imediatamente, por que tal empenho vai mal. 0 próprio gesto de rejeitar o prazer - "Basta de auto-indulgência decadente! Renuncie e se purifique!" - produz por si um prazerexcedente. Não exalam todos os universos "totalitários", que demandam de seus seguidores um violento (auto)sacrifício à causa, o mau cheiro da fascinação por uma jouissance obscena letal? De modo inverso, uma vida orientada pela busca do prazer acarretará a severa disciplina de uma "vida saudável" - corrida, dietas e relaxamento mental - para ser desfrutada ao máximo. A ordem do superego para se divertir é entrelaçada de forma imanente com a lógica do sacrifício. Ambas formam um ciclo vicioso, em que cada extremo apoia o outro. A escolha nunca é simplesmente entre fazer seu dever ou se esforçar para ter prazer e satisfação. A escolha elementar é sempre redobrada por uma adicional, qual seja, entre elevar 
o esforço pelo prazer a um dever supremo, e cumprir o dever não pelo dever em si, mas pelas gratificações que provoca. No primeiro caso, os prazeres são o meu dever, e o esforço "patológico" pelo prazer está localizado no espaço formal do dever. No segundo caso, o dever é o meu prazer, e cumprir meu dever se situa no espaço formal das satisfações "patológicas".

\section{DEFESA CONTRA O PODER?}

Mas se os direitos humanos, enquanto oposição ao fundamentalismo e busca pela felicidade, levam-nos a contradições inacessíveis, não são eles, afinal de contas, uma defesa contra 0 excesso de poder? Em suas análises sobre 1848, Marx formulou a estranha lógica de que o poder se dá "em excesso" por conta de sua própria natureza. No Dezoito brumário de Luis Bonaparte e em As lutas de classe em França, ele "complicou" de uma forma devidamente dialética a lógica da representação social (agentes políticos representando classes e forças econômicas). Ao fazê-lo, ele foi muito além da noção usual dessas "complicações", segundo a qual a representação política nunca reflete diretamente a estrutura social - um único agente político pode representar diferentes grupos sociais, por exemplo; ou uma classe pode renunciar a sua representação direta e deixar a outro o trabalho de assegurar as condições político-jurídicas de seu governo, assim como o fez a classe capitalista inglesa ao deixar à aristocracia o exercício do poder político. A análise de Marx aponta para aquilo que Lacan, mais de um século depois, articularia como a "lógica do significante". A propósito do Partido da Ordem, formado após a derrota da insurreição de junho, Marx escreveu que somente a vitória eleitoral em 10 de dezembro de Luís Bonaparte permitiu a tal partido "remover" de seu círculo social os republicanos burgueses

e revelou-se o segredo de sua existência, a coalizão de orleanistas e legitimistas em um partido. A classe burguesa dividiu-se em duas grandes frações que, alternadamente - os grandes proprietários de terra durante a monarquia restaurada e a aristocracia das finanças e os burgueses industriais durante a Monarquia de julho - mantiveram um monopólio de poder. Bourbon era 0 título monárquico para a influência predominante dos interesses de uma fração. Órleans era o título monárquico para a influência predominante dos interesses de outra fração - o domínio sem nome da república foi o único no qual ambas as frações puderam manter, com igual poder, o interesse de classe 
comum sem abandonar sua rivalidade mútua (MARX e ENGELS, 1969, p. $83)^{5}$.

Esta, então, é a primeira complicação. Quando lidamos com dois ou mais grupos socio-econômicos, seus interesses em comum podem apenas ser representados sob o disfarce da negação de suas premissas compartilhadas: 0 denominador comum das duas frações monárquicas não é a monarquia, mas sim o republicanismo. (Assim como hoje em que o único agente político que representa de forma consistente os interesses do capital propriamente dito, na sua universalidade, acima de frações particulares, é a "sócio-liberal" Terceira Via). Por conseguinte, no Dezoito Brumário, Marx disseca a composição da Sociedade de 10 de Dezembro, o exército privado de criminosos de Luís Napoleão:

Lado a lado com roués ${ }^{6}$ decadentes, de duvidosos meios de subsistência e de origem duvidosa, juntamente com rebentos arruinados e aventureiros da burguesia, havia vagabundos, soldados desligados do exército, presidiários libertos, escravos desertores de galés, vigaristas, charlatões, Lazzaroni, batedores de carteira, trapaceiros, jogadores, maquereaus $^{8}$, donos de bordéis, carregadores, literatos, tocadores de realejo, trapeiros, amoladores de facas, soldadores ambulantes, mendigos; em suma, toda essa massa indefinida e desagregada, jogada de lá para cá, a qual os franceses chamam La bohème; com estes elementos afins, Bonaparte formou o núcleo da Sociedade 10 de Dezembro (...) Este Bonaparte, que se constitui em chefe do lumpemproletariado, que só então redescobre, em forma de massa, os interesses que pessoalmente persegue, que reconhece nesta escória, neste refugo e rebotalho de todas as classes, a única classe sobre a qual ele pode apoiar-se incondicionalmente, é o verdadeiro Bonaparte, o Bonarparte sans phrases ${ }^{9}$ (MARX e ENGELS, 1975, p. 149).

A lógica do Partido da Ordem é aqui trazida à sua conclusão radical. Da mesma forma que o único denominador comum de todas as frações monárquicas

\footnotetext{
${ }^{5}$ N. T. Nas passagens dos textos de Marx, cotejamos com as traduções brasileiras da coleção Os Pensadores (Abril Cultural, 1978) e da Expressão Popular (2008), de onde tiramos algumas notas explicativas.

${ }^{6}$ N. T. No original, em francês, "devassos, interesseiros, sem escrúpulos".

${ }^{7} \mathrm{~N}$. T. Na Itália, forma pela qual se designavam os lumpemproletários.

${ }^{8}$ N. T. No original, em francês, "cafetões".

${ }^{9}$ N. T. No original, em francês, "sem rodeios".
} 
é o republicanismo, o único denominador comum de todas as classes é 0 excremento em excesso, o refugo, o resíduo de todas as classes. Isto é, na medida em que o líder se considere a si mesmo como estando acima dos interesses de classe, sua base de classe imediata pode ser apenas o resíduo de excrementos de todas as classes, os rejeitados sem classe de cada classe. E, como Marx desenvolveu em outra passagem, é este apoio do "abjeto social" que permite a Bonaparte trocar de posição segundo sua necessidade, representando, por sua vez, cada classe contra as demais.

Enquanto autoridade executiva que se fez independente, Bonaparte considera que sua tarefa é salvaguardar a "ordem burguesa". Mas a força desta ordem burguesa repousa sobre a classe média. Ele se apresenta, portanto, como representante da classe média e emite decretos neste sentido. Todavia, ele somente é alguém porque quebrou o poder desta classe média, e segue quebrando-o diariamente. Ele se apresenta, portanto, como adversário do poder político e literário da classe média (MARX e ENGELS, 1975, p. 194).

Mas, há mais. Para que este sistema funcione - isto é, para que o líder se levante sobre as classes e não atue como representante direto de uma classe qualquer-ele também tem que atuar como representante de uma classe particular: da classe que, precisamente, não está suficientemente constituída para atuar como um agente unido que demanda representação ativa. Esta classe de pessoas que não podem representar a si mesmas e, assim, pode somente ser representadas é, por certo, a classe dos pequenos camponeses, que

formam um vasta massa, cujos membros vivem em condições similares, mas sem estabelecer múltiplas relações entre si. 0 seu modo de produção os isola uns aos outros ao invés de reuni-los em um intercâmbio mútuo. (...) Eles são, consequentemente, incapazes de fazer valer seus interesses de classe em seu próprio nome, seja através de um parlamento, seja por meio de uma convenção. Eles não podem representar-se, precisam ser representados. Seu representante deve, ao mesmo tempo, aparecer como seu senhor, como uma autoridade sobre eles, como um poder governamental ilimitado que os protege contra as outras classes e que do alto os envia chuva e sol. A influência política dos pequenos camponeses, portanto, encontra sua expressão final com o poder executivo que subordina a sociedade a si mesmo (MARX e ENGELS, 1975, p. 187-188).

Estas três características juntas formam a estrutura paradoxal da representação populista bonapartista: manter-se por cima de todas as classes, trocando entre elas, implica uma dependência direta sobre o abjeto/resíduo de 
todas as classes, aliado à referência última à classe daqueles que não são capazes de agir como um agente coletivo que demanda representação política. Este paradoxo baseia-se no excesso constitutivo da representação sobre os representados. De acordo com a lei, o poder do Estado apenas representa o interesse de seus súditos; está a serviço deles, é responsável por eles e está, ele mesmo, sujeito a seu controle. Entretanto, de acordo com o superego subjacente, a mensagem pública de responsabilidade é complementada pela mensagem obscena do exercício incondicional de poder: "As leis não me constrangem realmente, eu posso fazer a você o que eu quiser, eu posso tratá-lo como culpado se assim o decido, eu posso destruí-lo por um capricho". Este excesso obsceno é um componente necessário da noção de soberania. A assimetria, aqui, é estrutural: a lei pode apenas sustentar sua autoridade se os súditos escutarem nelas o eco da obscena e incondicional auto-afirmação do poder.

Este excesso de poder nos leva ao argumento fundamental contra as "grandes" intervenções políticas, as quais têm por objetivo uma transformação global: as experiências aterrorizantes do século XX, uma série de catástrofes que precipitou violentos desastres em uma escala sem precedente. Há três principais teorizações sobre estas catástrofes. Em primeiro lugar, a visão simbolizada pelo nome de Habermas: o Esclarecimento é, em si, um processo emancipatório positivo sem potencial totalitário inerente; as catástrofes que ocorreram apenas indicam que permanece um projeto inacabado, e nossa tarefa deve ser completar este projeto. Em segundo lugar, a visão associada com a Dialética do Esclarecimento de Adorno e Horkheimer e, hoje, com Agamben. A propensão "totalitária" do Esclarecimento é inerente e definitiva, o "mundo administrado" é sua verdadeira consequência, e os campos de concentração e os genocídios são um tipo de ponto final teleológico negativo de toda a história do Ocidente. Em terceiro lugar, a visão desenvolvida nos trabalhos de Etienne Balibar, entre outros: a modernidade inaugura um campo de novas liberdades, mas, ao mesmo tempo, de novos perigos, e não há garantia teleológica suprema do resultado. A contenda segue aberta e sem estar decidida.

0 ponto de partida do texto de Balibar sobre a violência é a insuficiência da noção hegeliana-marxista padrão de "converter" a violência em um instrumento da Razão histórica, uma força que gera uma nova formação social (BALIBAR, 2002). A brutalidade "irracional" da violência é, portanto, aufgehoben, "negada" no sentido hegeliano estrito, reduzida a uma "mancha" particular que contribui para a harmonia geral do progresso histórico. 0 século XX nos enfrentou com 
catástrofes - algumas dirigidas contra as forças políticas marxistas, outras geradas pelo próprio engajamento marxista - que não podem ser "racionalizadas" desta maneira. Sua instrumentalização que as converte em ferramentas da Astúcia da Razão não é apenas eticamente inaceitável, mas também teoricamente equivocada, ideológica no sentido mais forte do termo. Em sua cuidadosa leitura de Marx, Balibar, todavia, distingue uma oscilação entre esta "teoria da conversão" teleológica da violência, e a noção muito mais interessante da história como um processo em aberto de lutas antagônicas, cujo resultado final "positivo" não está garantido por qualquer necessidade histórica que o englobe.

Balibar argumenta que, por razões estruturais necessárias, o marxismo é incapaz de pensar no excesso de violência que não pode ser integrado na narrativa do Progresso histórico. De forma mais específica, o marxismo é incapaz de gerar uma teoria adequada do fascismo e do stalinismo e seus resultados "extremos", o holocausto [Shoah] e o gulag. Nossa tarefa é, portanto, dupla: implantar uma teoria da violência histórica como algo que não pode ser instrumentalizado por nenhum agente político, o que ameaça tragar o próprio agente em um ciclo vicioso de auto-destruição; e também propor a questão de como converter o processo revolucionário em si em uma força civilizadora. Como um contra-exemplo, tomemos o processo que levou ao Massacre do Dia de São Bartolomeu. 0 objetivo de Catarina de Médici era limitado e preciso: foi uma conspiração maquiavélica sua para assinar o almirante de Coligny - um poderoso protestante partidário da guerra contra a Espanha na Holanda - e deixar a culpa cair sobre a excessivamente poderosa família católica dos Guisa. Catarina buscava, assim, traçar a queda das duas casas-reais que representavam um ameaça à unidade do Estado francês. No entanto, a tentativa de colocar seus inimigos uns contra os outros degenerou em um frenesi incontrolável de sangue. Em seu cruel pragmatismo, Catarina foi cega às paixões com as quais os homens se agarram às suas crenças.

Os insights de Hanna Arendt são cruciais aqui, ao enfatizar a distinção entre o poder político e o mero exercício da violência. As organizações dirigidas por uma autoridade apolítica direta - Exército, Igreja, escola - representam exemplos de violência (Gewalt), e não de poder político no sentido estrito do termo (ARENDT, 1970). Neste ponto, entretanto, temos que recordar a distinção entre a lei pública simbólica e os seus complementos obscenos. A noção deste duplo complemento obsceno de poder implica que não há poder sem violência. 0 espaço político nunca é "puro", mas sempre implica algum tipo de confiança na violência pré-política. Por certo, a relação entre poder político e violência pré-política é de implicação 
mútua. A violência não é apenas o complemento necessário do poder, mas o próprio poder já está sempre na raiz de toda relação aparentemente "apolítica" de violência. A violência aceita e a relação direta de subordinação no interior do Exército, da Igreja, da família e de outras formas sociais "apolíticas" são, em si mesmas, a reificação de certa luta ético-política. A tarefa das análises críticas é perceber o processo político oculto que sustenta todos essas relações "a" ou "pré" políticas. Na sociedade humana, a política é o princípio estrutural que a tudo engloba, assim, qualquer neutralização de algum conteúdo parcial indicando-o como "apolítico" é um gesto político par excellence.

\section{A PUREZA HUMANITÁRIA}

Dentro deste contexto podemos situar a proeminente questão dos direitos humanos: os direitos daqueles que estão morrendo de fome ou expostos a uma violência assassina. Rony Brauman, que coordenou a ajuda à Saravejo, demonstrou como a própria apresentação da crise como "humanitária", a própria reformulação de um conflito político-militar em termos humanitários, foi sustentada por uma escolha eminentemente política - basicamente, para tomar partido pelo lado sérvio do conflito. A celebração da "intervenção humanitária" na Iugoslávia tomou o lugar de um discurso político, segundo argumenta Brauman, desqualificando, assim, de antemão, todo debate contrário (BRAUMAN, 2004, p. 398-199 e 416).

A partir deste insight particular podemos problematizar, em um nível geral, a política supostamente despolitizada dos direitos humanos e vê-la como uma ideologia do intervencionismo militar, que serve a fins político-econômicos específicos. Como sugerido por Wendy Brown a respeito de Michel Ignatieff, tal humanitarismo

se apresenta como espécie de uma anti-política, uma defesa pura dos inocentes e dos impotentes contra o poder, uma defesa pura do indivíduo contra as máquinas imensas e potencialmente cruéis ou despóticas da cultura, do Estado, da guerra, do conflito étnico, do tribalismo, do patriarcado, e outras mobilizações ou exemplos do poder coletivo contra os indivíduos (BROWN, 2004, p. 453).

Entretanto, a questão é: entre aqueles que intervêm em nome dos direitos humanos, que tipo de politização colocam em movimento contra os poderes a que eles se opõem? Eles são partidários de uma formulação diferente de justiça ou se 
opõem a projetos de justiça coletivos? Por exemplo, está claro que a derrubada de Saddam, liderada pelos Estados Unidos, legitimada em termos de pôr fim ao sofrimento do povo iraquiano, não foi apenas motivada por interesses políticoeconômicos pragmáticos, mas também contou com uma ideia determinada acerca das condições econômicas e políticas sob as quais era para ser entregue a "liberdade" ao povo iraquiano: capitalismo liberal-democrático, inserção na economia de mercado mundial, etc. A política meramente humanitária e antipolítica de apenas prevenir o sofrimento equivale, por tanto, a uma proibição implícita de elaborar um verdadeiro projeto coletivo de transformação sóciopolítico.

Em um plano ainda mais geral, poderíamos problematizar a oposição entre os direitos humanos universais (pré-políticos), possuídos por qualquer ser humano "enquanto tal", e os direitos políticos específicos de um cidadão ou membro de uma comunidade política particular. Neste sentido, Balibar (2004, p. 320-321) argumenta pela "reversão da relação teórica e histórica entre "homem" e "cidadão" que prossegue "explicando como o homem é formado pela cidadania e não a cidadania pelo homem". Balibar faz alusão aqui ao insight de Arendt sobre a condição de refugiados:

A concepção dos direitos humanos baseada na suposta existência de um ser humano como tal rompeu-se no exato momento em que aqueles que declaravam acreditar nesta concepção foram, pela primeira vez, confrontados com pessoas que tinham perdido, de fato, todas as demais qualidades e relações específicas, exceto a de seguir sendo humanas (ARENDT, 1958, p. 297).

Esta direção, por certo, conduz diretamente à noção de bomo sacer de Agamben enquanto um ser humano reduzido à "vida nua". Em uma dialética propriamente hegeliana do universal e do particular, o ser humano - em um único movimento - deixa de ser reconhecido ou tratado como humano precisamente quando fica desprovido de uma identidade particular sócio-política que responde por esta cidadania determinada ${ }^{10}$. Paradoxalmente, fico privado dos direitos humanos no momento preciso em que sou reduzido a um ser humano "em geral", e venho a ser, portanto, o portador ideal daqueles "direitos humanos universais", os quais pertencem a mim independentemente de minha profissão, sexo, cidadania, religião, identidade étnica, etc.

${ }^{10}$ Ver Agamben (1998). 
0 que acontece, então, com os direitos humanos quando estes são os direitos do homo sacer, daqueles excluídos da comunidade política; isto é, quando estes não são úteis, porque são os direitos daqueles que, precisamente, não têm direitos e são tratados como não humanos? Jacques Rancière propõe uma notável inversão dialética: "Quando eles não são úteis, se faz o mesmo que pessoas caridosas fazem com suas roupas velhas. Elas são dadas aos pobres. Aqueles direitos que parecem inúteis em seu lugar são mandados para o exterior, junto a remédios e roupas, a pessoas desprovidas de remédios, roupas e direitos". Todavia, eles não se tornam vazios, porque "nomes políticos e lugares políticos nunca se tornam meramente vazios". Ao invés disso, o vazio é preenchido por alguém ou algo distinto.

Se aquele que sofre uma repressão desumana é incapaz de decretar os direitos humanos que são seu último recurso, então alguém tem que herdar seus direitos para decretá-los em outro lugar. Isto é o que chamo de "direito de interferência humanitária" - um direito que algumas nações adotam para suposto benefício de populações vitimizadas, e, muito frequentemente, contra a recomendação das próprias organizações humanitárias. 0 "direito à interferência humanitária" poderia ser descrito como uma espécie de "devolução ao remetente": os direitos não usados, que foram enviados aos carentes em direitos, são devolvidos aos remetentes (RANCIÈRE, 2004, p. 307309).

Assim, para colocar na forma leninista: hoje, o que os "direitos humanos de vítimas sofredoras do Terceiro Mundo" efetivamente significam, no discurso dominante, é o direito das próprias potências do Ocidente de intervir política, econômica, cultural e militarmente em países do Terceiro Mundo de sua escolha, em nome da defesa dos direitos humanos. A referência à formula de Lacan da comunicação (na qual o remetente recebe sua própria mensagem de volta do receptor-destinatário em sua forma invertida, isto é, verdadeira) vem bem ao caso aqui. No discurso dominante do intervencionismo humanitário, o Ocidente desenvolvido está, efetivamente, recebendo de volta, do Terceiro Mundo vitimizado, sua própria mensagem em sua forma verdadeira.

No momento, então, em que os direitos humanos são despolitizados, o discurso relacionado a eles precisa mudar: a oposição pré-política entre o Bem e o Mal deve ser mais uma vez mobilizada. Portanto, o atual "novo reino da ética", claramente invocado, por exemplo, no trabalho de Ignatieff, conta com um ato violento de despolitização, privando o outro vitimizado de qualquer subjetivação política. E, como assinalado por Rancière, o humanitarismo liberal à la Ignatieff 
vai ao encontro, inesperadamente, da posição "radical" de Foucault ou Agambem com relação a esta despolitização: a noção desses autores de "biopolítica", como a culminação do pensamento ocidental, acaba caindo em um tipo de "armadilha ontológica", na qual campos de concentração aparecem como destinos ontológicos: "cada um de nós poderia estar na situação de refugiado em um campo. Qualquer diferença entre a democracia e o totalitarismo se esvai e qualquer prática política prova estar já enredada na armadilha biopolítica" (RANCIÈRE, 2004, p. 301).

Chegamos, portanto, a uma posição "anti-essencialista" padrão, uma espécie de versão política da noção de Foucault de que o sexo é gerado pela multiplicidade de práticas de sexualidade. 0 "homem", o portador dos direitos humanos, é gerado por um conjunto de práticas políticas que materializam a cidadania; os "direitos humanos" são, enquanto tais, uma falsa universalidade ideológica, que mascara e legitima a política concreta do imperialismo, das intervenções militares e do neocolonialismo ocidentais. Isto é, entretanto, suficiente?

\section{O RETORNO DA UNIVERSALIDADE}

A interpretação sintomática marxista pode demonstrar, de forma convincente, o conteúdo que fornece à noção de direitos humanos o seu específico giro ideológico burguês: os direitos humanos universais são, com efeito, o direito dos homens brancos proprietários a trocar livremente no mercado, explorar trabalhadores e mulheres, e exercer dominação política. Esta identificação do conteúdo particular que hegemoniza a forma universal é, contudo, somente a metade da história. Sua outra metade crucial consiste em fazer uma questão suplementar ainda mais difícil: aquela sobre a emergência da própria forma de universalidade. Como - em que condições históricas específicas - a universalidade abstrata se tornou um "fato da vida (social)"? Em que condições os indivíduos se experimentam a si mesmos enquanto sujeitos de direitos humanos universais? Aqui reside o ponto central da análise de Marx do "fetichismo da mercadoria": em uma sociedade na qual predomina a troca de mercadoria, os indivíduos, em sua vida diária, fazem referência a si mesmos e aos objetos que encontram como personificações contingentes de noções universais abstratas. 0 que eu sou, em relação às minhas experiências sociais e culturais concretas, é vivenciado como contingente, pois o que me define fundamentalmente é a capacidade universal "abstrata" de pensar ou de trabalhar. Do mesmo modo, qualquer objeto que 
possa satisfazer meu desejo é vivenciado como contingente, pois o meu desejo é concebido como uma capacidade formal "abstrata", indiferente à multiplicidade de objetos particulares que podem, mas sem nunca conseguir completamente, satisfazê-lo.

Ou tomemos o exemplo da "profissão": a noção moderna de profissão significa que me experimento como um indivíduo que não "nasceu" diretamente no seu papel social. No que me transformarei depende da interação entre circunstâncias sociais contingentes e minha livre escolha. Neste sentido, o indivíduo de hoje tem uma profissão - como eletricista, garçom ou conferencista -, enquanto não faz sentido alegar que o servo medieval era camponês por profissão. Nas condições sociais específicas da troca de mercadorias e da economia de mercado global, a "abstração" torna-se uma característica direta da vida social atual, a forma em que indivíduos concretos se comportam e se relacionam com seus destinos e com seu ambiente social. A este respeito, Marx compartilha a ideia de Hegel, segundo a qual a universalidade surge "por si mesma" somente quando os indivíduos não mais identificam completamente o âmago de seu ser com a sua situação particular; somente na medida em que se experimentam como "deslocados" para sempre dela. A existência concreta da universalidade é, desta maneira, o indivíduo sem um lugar adequado no edifício social. Portanto, o modo de aparição da universalidade, sua entrada na existência real, é um ato extremamente violento de romper o equilíbrio orgânico anterior.

Não é suficiente assinalar a gasta noção marxista sobre a diferença entre a aparência ideológica da forma jurídica universal e os interesses particulares que efetivamente o sustentam. Neste ponto, o contra-argumento (apresentado, entre outros, por Lefort e Rancière), segundo o qual a forma nunca é "mera" forma, mas envolve uma dinâmica própria, que deixa traços na materialidade da vida social, é totalmente válido. Foi a "liberdade formal" burguesa que colocou em movimento as demandas políticas e práticas bem "substanciais" do feminismo e do sindicalismo. A ênfase básica de Rancière reside na ambiguidade radical da noção marxista da "diferença" [gap] entre a democracia formal - os Direitos do Homem, as liberdades políticas - e a realidade econômica de exploração e dominação. Esta diferença pode ser lida na forma "sintomática" padrão: a democracia formal é uma expressão necessária, porém ilusória de uma realidade social concreta de exploração e de dominação de classe. Contudo, também pode ser lida em um sentido mais subversivo de uma tensão na qual a "aparência" da égaliberté não é uma "mera aparência”, mas contém uma eficácia própria, o 
que a permite pôr em movimento a rearticulação das relações socioeconômicas reais por meio de sua progressiva "politização". Por que às mulheres também não deveria ser permito o voto? Por que as condições de trabalho não deveriam ser também uma questão de interesse público?

Poderíamos aplicar neste momento o velho termo de Lévi-Strauss de "eficácia simbólica": a aparência da "égalibertê" é uma ficção simbólica que, como tal, possui eficácia real própria; a tentativa particularmente cética de reduzila a uma mera ilusão, que oculta uma realidade diferente, deve ser repelida. Não é suficiente apenas firmar uma articulação autêntica de uma experiência do mundo e da vida que depois é reapropriada por aqueles que estão no poder para servir aos seus interesses particulares ou para fazer de seus súditos dóceis peças na engrenagem social. Muito mais interessante é o processo oposto, no qual algo, que era originalmente um edifício ideológico imposto por colonizadores, é tomado subitamente em seu conjunto pelos súditos como uma maneira de articular suas queixas "autênticas". Um caso clássico seria o da Virgem de Guadalupe, no México recém-colonizado: com a sua aparição a um humilde índio, o cristianismo - que até então servia como uma ideologia imposta pelos colonizadores espanhóis - foi apropriado pela população indígena como um meio para simbolizar sua terrível condição.

Rancière propôs uma solução muito elegante à antinomia entre os direitos humanos, pertencentes ao "homem como tal", e a politização dos cidadãos. Embora os direitos humanos não possam ser postulados como um Além a-histórico e "essecialista" em relação à esfera contingente das lutas políticas, como "direitos naturais do homem" universais dissociados da história, eles também não deveriam ser descartados como um fetiche reificado, produto do processo histórico concreto de politização dos cidadãos. A diferença entre a universalidade dos direitos humanos e os direitos políticos dos cidadãos não é, portanto, uma diferença entre a universalidade do homem e a especificidade da esfera política. Mais propriamente, esta diferença "separa toda a sociedade de si mesma" (RANCIÈRE, 2004, p. 305). Longe de serem pré-políticos, os "direitos humanos universais" designam o espaço preciso da politização propriamente dita, eles equivalem ao direito de universalidade como tal - o direito de um agente político em declarar sua não-coincidência radical consigo mesmo (na sua identidade particular), para postular a si mesmo como o "supra-numerário", aquele sem lugar adequado no edifício social; e, portanto, como um agente da universalidade do social em si. Por conseguinte, o paradoxo é muito preciso e simétrico em relação ao paradoxo dos 
direitos humanos universais como os direitos daqueles reduzidos à inumanidade. No exato momento em que tentamos conceber os direitos políticos dos cidadãos sem fazer referência aos direitos humanos universais "meta-políticos", perdemos a própria política; isto é, reduzimos a política a um jogo "pós-político" de negociação de interesses particulares.

\section{REFERÊNCIAS}

AGAMBEN, Giorgio. Homo sacer. Stanford, 1998. [Homo sacer: o poder soberano e a vida nua. Belo Horizonte: UFMG, 2002.]

ARENDT, Hannah. On Violence. New York, 1970. [Sobre a violência. Rio de Janeiro: Civilização Brasileira, 2009].

. The Origins of Totalitarianism. New York, 1958. [As origens do totalitarismo. São Paulo: Cia. das Letras, 1989].

BALIBAR, Etienne. 'Gewalt': entry for Historisch-Kritisches Wörterbuch des Marxismus, vol. 5, Hamburg: Wolfgang Fritz Haug, 2002.

. Is a Philosophy of Human Civic Rights Possible? South Atlantic

Quarterly, Durham, v. 103, n. 2-3, 2004.

BRAUMAN, Rony. From Philanthropy to Humanitarianism. South Atlantic Quarterly, Durham, v. 103, n. 2-3, 2004.

BROWN, Wendy. Human Rights as the Politics of Fatalism, South Atlantic Quarterly, Durham, v. 103, n. 2-3, 2004.

JEZERNIK, Bozidar. Wild Europe: The Balkans in the Gaze of Western Travellers. London, 2004.

MARX, Karl; ENGELS, Friedrich. Selected Works, vol. I. Moscow, 1969.

MARX, Karl; ENGELS, Friedrich. Selected Works, vol. XI. Moscow, 1975. [publicações em português citadas: Karl Marx, Os pensadores. São Paulo: Abril Cultural, 1978 e A revolução antes da revolução, vol. II. São Paulo: Expressão Popular, 2008].

RANCIÈRE, Jacques. Who is the Subject of the Rights of Man? South Atlantic Quarterly, Durham, v. 103, n. 2-3, 2004. 